\title{
CRIME, DETERRENCE, AND DEMOCRACY
}

\section{Libor Dušek}
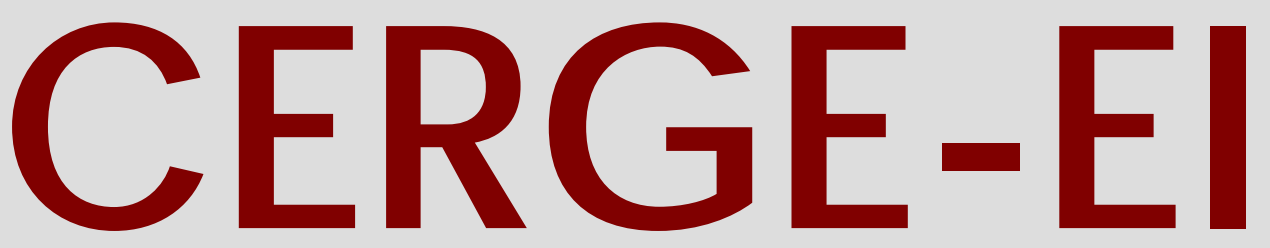

Charles University Centerfor Economic Research and Graduate Education Academy of Sciences of the Czech Republic Ec onomic s Institute 


\title{
Working Paper Series 260 (ISSN 1211-3298)
}

\section{Crime, Deterrence, and Democracy}

\author{
Libor Dušek
}

CERGE-EI

Prague, September 2005 
ISBN 80-7343-068-1 (Univerzita Karlova v Praze, CERGE)

ISBN 80-7344-057-1 (Národohospodářský ústav AV ČR, Praha) 


\title{
Crime, Deterrence, and Democracy*
}

\author{
Libor Dušek ${ }^{\dagger}$ \\ CERGE-EI ${ }^{\ddagger}$
}

September 2005

\begin{abstract}
We provide new evidence on the effect of deterrence on crime using the experience of a transition country (the Czech Republic) as a quasi-natural experiment. The arrival of democracy in 1989 was accompanied by sharp reductions in all measures of deterrence and sharp increases in crime rates. We test whether deterrence, rather than other factors, was responsible for the post-1989 growth in crime on a panel dataset of Czech regions. The results show significant deterrence effects for robberies and thefts that are quantitatively similar to those found in previous literature, but insignificant deterrence effects for murders and rapes.
\end{abstract}

\begin{abstract}
Abstrakt
Článek přináší novou evidenci o vlivu výše trestu a pravděpodobnosti trestu na kriminalitu. Využívá zkušenosti transitivní země (České republiky) jakožto kvazi-experimentu. Po revoluci roku 1989 výrazne klesla pravděpodobnost, že zločinec bude obžalován a odsouzen, a zároveň výrazně vzrostla kriminalita. Na panelovém souboru regionů České republiky testujeme, zda propad ve výši a pravděpodobnosti trestu, a nikoli jiné faktory, byly prŕččinou růstu kriminality po roce 1989. Výsledky ukazují, že trest má výrazný odstrašující efekt na krádeže a loupeže (kvantitativně srovnatelný s odhady v mezinárodní literatuře), ale nemá statisticky významný efekt na vraždy a znásilnění.
\end{abstract}

Keywords: crime, deterrence

JEL classification: K14, K42, P37

*I greatly appreciate comments and suggestions from Randall Filer, Jan Kmenta, William Trumbull, Bruce Benson, and participants at the GDN regional conference. Tomáš Konečný and Pavel Dvořák provided excellent research assistance. Financial support from GDN grant RRC IV-22/2004 is gratefully acknowledged.

${ }^{\dagger}$ Email: libor.dusek@cerge-ei.cz

$¥$ A joint workplace of the Center for Economic Research and Graduate Education, Charles University, Prague, and the Economics Institute of the Academy of Sciences of the Czech Republic. Address: CERGE-EI, P.O. Box 882, Politických vězňů 7, Prague 1, 111 21, Czech Republic 


\section{Introduction}

Numerous studies have tested the basic prediction of the economic model of crime that an increase in deterrence (the probability and severity of punishment) leads to a reduction in the number of offenses. Most studies use data aggregated at the level of counties, states, or countries, and exploit variation in the empirical measures of the individually perceived probability and severity of punishment across geographical units or over time (Ehrlich [1973], Ehrlich [1975], Cornwell and Trumbull [1994], Soares [2004]). More recent papers have exploited the variation in the deterrence variables generated by quasi-natural experiments, such as Levitt's (1998) and Lee's (2005) analysis of juvenile crime which exploits the fact that individuals become subject to a stricter criminal justice system as they reach adulthood. The general conclusion of this literature is that the higher probability of arrest and conviction and, to a smaller extent, the severity of punishment do deter crime, although there is disagreement about the magnitude of deterrence effects and the extent to which estimates capture a true causal relationship. ${ }^{1}$

In this paper, we provide new evidence on the effect of deterrence on crime by using the transition of a Central European country (the Czech Republic) from a communist regime to democracy as a quasi-natural experiment. The attractiveness of this approach comes from the fact that the sudden collapse of communism in November 1989 was followed by very sharp declines in the probability that an offender is arrested, charged, and convicted. This provides variation in deterrence that is rarely observed in datasets covering a single jurisdiction. For example, in 1988, the ratio of people charged with robbery to the number of robberies was $78 \%$; of those charged with robbery, $82 \%$ were convicted and $85 \%$ of those convicted were sentenced to prison. $^{2}$ Just four years later, only $36 \%$ of robberies translated into charges, only $53 \%$ of charges resulted in convictions and $76 \%$ of convicts were sentenced to prison.

Similar declines can be observed for other offenses.

\footnotetext{
${ }^{1}$ Taylor (1978), Cornwell and Trumbull (1994), and Levitt (1997).

${ }^{2}$ Source: Author's own computation.
} 
At the same time, crime has turned out to be an unexpected and unpleasant side effect of the new democracy. The murder rate, i.e., the number of murders per 100,000 inhabitants, increased from 0.93 in 1988 to 2.5 in 1992 and continued to rise until 1998 when it reached its peak of 3.35 (see Figure 1). Just during the first post-revolution year of 1990, the theft and burglary rate jumped from 196 to 960 - almost a 5-fold increase! After reaching a peak of 2400, the theft and burglary rate has stabilized at around 1600, i.e., about 8 times more than what it used to be under communism. ${ }^{3}$ Crime became one of the major negative aspects of post1989 development and one of the major concerns of ordinary citizens as well as politicians. ${ }^{4}$

Testing the economic model of crime requires assembling sufficient evidence that such a rapid growth in crime was at least partly caused by weaker deterrence. We assembled a panel dataset of the Czech Republic's regions containing information on the number of offenses, criminal justice variables from which measures of deterrence can be constructed ${ }^{5}$, and several socioeconomic variables. There is substantial variation between regions not only in the levels of deterrence variables, but also in their change from the pre-1989 to the post-1989 period. We estimate the relationship between measures of deterrence and crime rates for six crime categories ${ }^{6}:$ murder, $^{2}$ robbery, theft (including burglary ${ }^{7}$ ), failure to support ${ }^{8}$, rape, and intentional in-

\footnotetext{
${ }^{3}$ The Czech Republic was no exception among the post-communist countries of Central and Eastern Europe. In Hungary, for example, the murder rate increased from 2.1 to 3.1 and the theft rate from 1023 to 2665 between 1988 and 1992. (Source: Statistical Yearbook of Hungary.)

${ }^{4}$ Tucek et al., (1999).

${ }^{5}$ Namely the number of suspects investigated for each type of offense, the number of suspects charged with each offense, the number of persons convicted, the number of persons sentenced to prison, and rough distribution of the length of prison sentence imposed.

${ }^{6}$ They are defined in sections $219,234,247,213,241$, and 221, respectively, of the Czech Criminal Code.

${ }^{7}$ The Czech Criminal Code does not make a distinction between thefts and burglaries, and this is also reflected in the crime statistics where burglaries and thefts are reported as one type of offense.

${ }^{8}$ Failure to support is defined as non-fulfilling one's legal duty to materially support another person, e.g. when a divorced father stops making the alimony payments, and it is punishable by up to 1 year of imprisonment, or up to 3 years of imprisonment if certain aggravating circumstances apply (sec. 213 of the Czech Criminal Code).
} 
jury $^{9}$. We use a "standard" regression framework adopted in earlier studies ${ }^{10}$ as well as a simultaneous equations model that captures the adjustments of deterrence to the past levels of crime rates. We find that deterrence has statistically and economically significant effect on robberies, thefts, intentional injuries, and, to smaller extent, the failure to support. However, we do not observe a statistically significant relationship between deterrence and the number of murders and rapes. Our estimates of the elasticity of the crime rate with respect to the probability of being charged lie between -0.6 and -0.78 in the case of robberies, and between -0.51 and -0.83 in the case of thefts. In accordance with the predictions of the economic model, the elasticities of the crime rate with respect to the conditional probability of conviction and the expected length of prison sentence are smaller in magnitude. For robberies and thefts, our estimates are surprisingly similar to those found in the studies on U.S. data, but for murders they are substantially different. We also predict how the crime rates would have evolved if all measures of deterrence had remained at the same level as in 1989 and find that more than half of the growth in robberies, thefts, and intentional injuries during the 1990's can be explained by the fall in deterrence.

A natural objection is that our estimates do not reflect the effect of weaker deterrence but the effect of various other shocks associated with the transition from communism to democracy which also contributed to the growth of crime. For example, replacing central planning with the very basic institutions of capitalism inevitably increased the gains from criminal activities: free trade made it easier to sell stolen goods abroad; open borders attracted crowds of tourists that are potential targets of robbers and thieves; higher incomes and higher income inequality increased the value of goods that can be stolen ${ }^{11}$; and the rise in entrepreneurial activity gave

\footnotetext{
${ }^{9}$ The Czech Criminal Code distinguishes four different offenses that involve injury (sections 221-224), depending on whether the injury was serious or not and whether it was committed intentionally or by negligence. In our dataset we work only with intentional, non-serious injuries (punishable by up to two years of imprisonment, or up to 5 years under certain aggravating circumstances).

${ }^{10}$ Ehrlich (1973), and Cornwell and Trumbull (1994).

${ }^{11}$ This can be well documented by the increase in the stock of consumer durables. The number of cars per 100 households rose from 62 (1990) to 70 (2000), and the number of refrigerators/freezers
} 
rise to new types of conflicts that potentially may be resolved by violence. Rising unemployment reduced the opportunity costs of criminal activities, especially among young males with low education who are traditionally most prone to engage in criminal activities. New social phenomena such as drugs, human trafficking, and organized crime have altered the nature (i.e. the distribution of costs and benefits) of crimes such as murders and robberies (Cejp 2003).

We do acknowledge the existence of such shocks. While we are able to measure some of them (e.g., changes in unemployment or income inequality), it would be fruitless to hope that all of them would ever be captured as observable variables in any dataset. Still, we have several reasons to think that our estimates of deterrence effects are not entirely driven by the unobserved shocks. First, some of the shocks were presumably common to all regions, or were specific to each region but uncorrelated with changes in deterrence in that region. Such shocks are captured by the year dummy variables and do not bias the estimates of coefficients on deterrence variables. Second, we look at crimes for which one can reasonably assume that their nature was unaffected by the change of the political regime (rape, failure to support, and intentional injury). ${ }^{12}$ However, deterrence has declined and the crime rates have increased since 1989 even in these crime categories. Our estimates do show a statistically significant relationship between deterrence and crime rates for failure to support and intentional injury (but not for rape), although the estimates are quantitatively different from robberies and thefts. Third, in the case of robberies, thefts and intentional injuries, the coefficients on year dummy variables provide an additional piece of evidence that our estimates are not picking up some other shocks correlated with deterrence. They jump up sharply from 1989 to 1990, and do not significantly change for the subsequent years even though the number of offenses continued to rise. Our interpretation of this result is that democracy was an immerose from 118 (1990) to 153 (2000). Data on less basic durables are not available until the mid1990's, but while video recorders and microwave ovens were a rarity in the socialist economy, there were 29 video recorders per 100 household in 1995, and 48 in 2000; likewise the number of microwave ovens rose from 13 (1995) to 45 (2000). (Source: Czech Republic Yearbooks.)

${ }^{12}$ Our choice of these crime categories was made not only on our prior belief that their nature did not change, but also on the fact that they are relatively numerous. 
diate, once-and-for-all shock that raised the level of crime while the continuing can again be explained by changes in the explanatory variables. Considered together, we think that the above arguments show by a "preponderance of the evidence" that our results do reflect a causal relationship between deterrence and crime.

The rest of paper is organized as follows. Section 2 discusses why democracy led to weaker deterrence and reviews earlier empirical literature on the relationship between crime and democracy. Section 3 describes the data sources. In section 4, we present the estimates and discuss their implications. Section 5 concludes.

\section{Democracy and deterrence}

Since we are treating the transition from communism to democracy as a source of variation in deterrence, it is worthwhile to discuss what caused such a large decline in deterrence. An important cause, we argue, was a wide range of democratic reforms that eliminated the oppressiveness and abuses in the communist system of (in)justice. The Velvet Revolution of 1989 granted citizens the same political and civil liberties that citizens of other Western European countries have enjoyed. In the area of criminal law and criminal procedure, the reforms generally restricted the powers of law enforcement authorities, protected citizens against certain practices of those authorities, and made punishment less severe. The specific legislative changes, implemented mostly in 1990 and $1993^{13}$, include: ${ }^{14}$

- Limits on arrests and detention. Under the old Criminal Procedure Code, the maximum period for which a person suspected of having committed a criminal offense could be detained or arrested was 48 hours. The 1990 amendment shortened the limit to 24 hours. The police's past disrespect of the limit on arrests was such a great concern for the drafters of the new constitution

\footnotetext{
${ }^{13}$ Czechoslovak Collection of Laws, 178/1990, and 292/1993.

${ }^{14}$ An overview of changes in criminal legislation is contained in Vujtech et al. (2001).
} 
that they specified a 24 hour limit in the Charter of Fundamental Rights and Freedoms. ${ }^{15}$

- The investigation procedure was substantially reorganized. The earlier procedure made it possible to carry out investigation, collect evidence, and inform the suspect about formal charges against him at the end of the investigation. The 1993 criminal procedure reform required all investigations to be carried out against a particular person who has to be informed about them from the beginning of the investigation.

- The rights of accused persons have been greatly expanded. Newly granted or extended were the right to remain silent, the right to have consultation with counsel at any time, the right to have counsel present during interrogation and other procedures, and the right to read all documentation regarding one's case during all stages of the criminal process. The tapping of telephone and other communication between the accused person and his counsel was disallowed without exception.

- Decisions regarding arrest and custody were shifted from the executive branch of government (state attorney) to the judicial branch (judge), and the reasons for which a person can be held in custody were narrowed.

- Release on bail was made possible.

- The severity of punishment was reduced by the elimination of the death penalty, by improvements in prison conditions, and there has been a gradual shift away from prison punishment, which is encouraged by legislative changes introducing new forms of punishment, such as public works, contractual settlement between offender and victim, and probation. ${ }^{16}$

- The creation of a Constitutional Court made it possible for citizens to seek remedies against violations of their rights in criminal procedures.

\footnotetext{
${ }^{15}$ Article 8, Czechoslovak Collection of Laws 23/1991.

${ }^{16}$ Amendments to the Criminal Code No. 152/1995 and 253/1997.
} 
Few people would prefer living in a society where the civil rights just described are denied. However, limiting the powers of law enforcement authorities and extending the rights of offenders increases the chance that a guilty offender is not convicted or punished. In the data, the institutional changes are summarized in a reduced probability than an offender is charged, convicted, and sentenced to prison, although it is hard to assess the contribution of specific changes. Anecdotal evidence includes a survey conducted among police officers at the end of 1990 who generally complained that "the 24 hour limit on the detention of suspects is the greatest obstacle in collecting evidence". ${ }^{17}$ In conversation with a judge, we were informed that a high fraction of cases in the early 1990's was dismissed by the courts or returned to investigators on purely procedural grounds, since the police were still adjusting to the new rules and were violating some of the newly granted rights of offenders in the meantime.

There is also a reason why deterrence would have declined even in the absence of changes in criminal procedure. Since the probability that an offender is arrested and convicted depends negatively on the total number of offenses committed, the unexpected increase in crime after 1989 for reasons unrelated to deterrence reduced the fraction of offenses the police and courts were able to clear, holding the enforcement resources (initially) fixed.

Since there are so many channels through which democracies can have a different number of offenses than totalitarian regimes, several authors have already investigated the relationship between democracy and crime. Williams and Serrins (1995) exploit the availability of data on crime in the Soviet Union during the perestroika years and observe that crime rates in the USSR are an order of magnitude below those in the USA, and that such a large difference can hardly be explained by differences in incomes, inequality or other economic factors. Andrienko and Shelley (2003) analyze the determinants of violent crime in post-soviet Russia. Their focus is on the influence of ethnic and political conflict rather than on more standard deterrence

\footnotetext{
${ }^{17}$ Tomin (1991).
} 
variables. Since their dataset covers years 1992-2000, they cannot assess how much the determinants of crime changed since the soviet period. Lin (2003) regresses crime rates in a panel of countries (already including some of the post-communist countries) against an index of democracy and finds that democracy is associated with increases in minor offences such as thefts but decreases in serious offenses such as murder. This finding contrasts sharply with the experience of the Czech Republic and other post-communist countries where all crimes, including murders, increased substantially. ${ }^{18} \mathrm{He}$ also finds that weaker deterrence is responsible for as much as $40-50 \%$ of the democracy's contribution to higher crime.

\section{Data}

Our panel dataset covers the years 1980 through 2000, and the units of observation are eight administrative regions ("kraje") that were the largest units of regional administration from 1960 till 1990. ${ }^{19}$ The measures of deterrence are constructed from two sources: The Criminal Statistics Yearbook ${ }^{20}$, published annually by the Ministry of Justice since the 1970's, and Statistics of Crime in the Territory of the Czech Republic ${ }^{21}$, an internal report published by the Police Directorate since 1992. For each crime category, the Ministry of Justice yearbook provides information about the number of cases completed at each step of the criminal process:

- Number of offenders investigated ${ }^{22}$ by the police - i.e., persons whom the police identify as suspects for a particular offense and raise formal accusations. Investigation need not imply arrest.

\footnotetext{
${ }^{18}$ Although it is true that, consistently with Lin's findings, a percentage increase in serious offenses (murders) was much lower than the percentage increase in minor offenses (thefts).

${ }^{19} \mathrm{On}$ average, regions have 1.25 million people. Fortunately for our purposes, the elimination of regional governments in 1990 and a creation of 14 new regional governments with different boundaries in 1998 did not affect the reporting of crime statistics since both the state police and courts remained organized along the old regional boundaries.

20 "Rocenka kriminality $v$ Ceske republice".

21 "Statistika kriminality na uzemi CR".

22 "Stíháno" in Czech.
} 
- Number of suspects charged ${ }^{23}$ with that offense - i.e. those against whom the evidence collected during investigation was strong enough so that the state attorney prosecuted them in court.

- Number of offenders convicted (found guilty by the court).

- Number of convicted offenders sentenced to prison.

- Number of offenders sentenced to a prison term of less than 6 months, 6 to 12 months, 1-2 years, 2-5 years, more than 5 years, life imprisonment or the death penalty. ${ }^{24}$

The methodology of collecting this information has not changed over the sample period and since the data comes directly out of regional state attorneys' and courts' records, we have no reason to suspect that they should suffer from any measurement error.

The variable to be explained, the actual number of offenses, is recorded in the Ministry of Justice yearbook up to 1994 and in the Police Yearbook since 1992. The methodology is somewhat different in each publication. The Police Yearbook contains the number of "records of criminal offense" - internal forms ${ }^{25}$ that police have to file each time they determine (based on their own investigative activities or reports from victims or witnesses) that a criminal offense was committed. This measure of crime probably best corresponds to the term "offenses known to police", the measure commonly used in international statistics. The explanation of the Justice Yearbook methodology requires some institutional background. According to the 1964 Criminal Procedure Code, the police would initiate an investigation against a particular offender if the offender was already known or against an "unknown offender" if he was not. The Justice Yearbook hence records the number of cases when the investigation of a known or unknown offender was initiated. This need

\footnotetext{
23 "Obžalováno" in Czech.

${ }^{24}$ From 1991, the reported intervals of prison sentences are less than 1 year, 5-15 years, more than 15 years, and life imprisonment. The death penalty was eliminated in 1990.

${ }^{25}$ So-called "Formular o trestnem cinu" in Czech.
} 
not be the same as the number of "records of criminal offense". The 1993 reform of the criminal procedure eliminated the concept of investigation against an unknown offender, and this statistic was later discontinued. In the years 1992-1994, both statistics are reported. Since measurement error in crime statistics is almost always downward biased, we always select the higher of these two measures as the number of offenses actually used in the analysis. ${ }^{26}$

We construct the following measures of deterrence:

$P^{A}$, the probability of being charged, measured as the number of people charged at court divided by the number of offenses. This effectively measures the "productivity of police" - its ability to identify and apprehend offenders and to collect the amount of evidence needed so as to bring the offender to court. ${ }^{27}$

$P^{C}$, the conditional probability of conviction, measured as the number of people convicted divided by the number of people charged. It captures the "productivity of the courts", as well as the burden of proof required to convict a defendant, and the degree of procedural rights granted to defendants.

$F$, the expected length of prison sentence faced by an offender who has been convicted. It is constructed as the ratio of persons sentenced to prison to the number of persons convicted, times the average length of a prison sentence. The length of prison sentence is computed from the information on the distribution of prison sentences. ${ }^{28}$ This formulation of expected punishment implicitly assumes that only prison imposes a positive cost on the offender. Such an assumption is of course too restrictive since the employment restrictions or check-ups by the probation officers, which are typically imposed with alternative punishments, carry real costs in

\footnotetext{
${ }^{26}$ The older measure gives a higher number of thefts and a lower number of robberies, rapes, and murders.

${ }^{27}$ U.S. studies typically use the probability that an offender is arrested rather than charged. Our data do not allow us to construct this particular measure, since investigation need not imply arrest, and not all suspects who are arrested are ultimately charged at court.

${ }^{28}$ For each interval, we assume that the average length of a sentence within that interval is equal to the midpoint of that interval, i.e. we take 3 months for the interval of 0-6 months, and so on. For punishments over 5 years, we assume the average length is 10 years. We imputed 50 years as the equivalent punishment for the death penalty or life imprisonment.
} 
addition to the social stigma associated with being convicted. Unfortunately, we have no way of imputing these additional costs into the computation of expected punishment. Still, if our measure of expected punishment falls because a smaller fraction of convicts is sentenced to prison, the actual expected punishment should also fall since the alternative punishment methods (probation, public works, fines) presumably impose lower costs on convicted offenders than prisons.

Two additional variables related to deterrence are the number of policemen employed by the Police of the Czech Republic ${ }^{29}$ in each region, which was provided to us by the personnel department at the Ministry of the Interior from their internal records, and the average real wage in the public sector which proxies for the cost of police.

We also use several socioeconomic variables that proxy the supply of potential offenders, the gains from committing crime, and the opportunity costs of crime (i.e., the potential offenders' gains from legitimate activities). The supply of potential offenders is proxied by the share of population aged 20-29. The gains from criminal activities are measured by the average wage in the region. The income opportunities in the legal sector are captured by the unemployment rate among males aged 20-29 and by a measure of wage inequality, the ratio of the average wage in the construction industry to the average wage in the financial services industry. ${ }^{30}$ All wage variables were deflated to real 1989 Czech koruna.

Tables 1 and 2 show the summary statistics. Table 1 presents the variation in deter-

\footnotetext{
${ }^{29}$ The Police of the Czech Republic is established by the central government. Larger municipalities typically have their own police forces which, however, have almost no authority over criminal cases. Our dataset does not contain information on the number of municipal policemen.

${ }^{30}$ All wage and unemployment data come from "Structure of Earnings Survey" and "Employment and Unemployment in the CR as Measured by the Labour Force Sample Survey" series produced by the Czech Statistical Office. For the years prior to 1990, no unemployment measures were available, and for the years 1990-1992, only the nation-wide unemployment rate was available. The very concept of unemployment was unknown under the centrally-planned economy, so we impute unemployment among men aged 20-29 to be zero in all regions for the years prior to 1990. For the years 1990-1992, we take the assumption that the ratio of the region-level unemployment rate among men aged 20-29 and the nation-wide unemployment rate was the same as in 1993, and impute the values accordingly. The same procedure was adopted for the wage data, where the industry-region observations on average wage are available since 1993 while for the years prior to 1993, only the region-wide average wage is available. Moreover, wage data were available for 1980, 1985, and 1990, but only since then at annual intervals; hence, the missing years during the 1980's were filled in by linear extrapolation.
} 
rence across regions in the years preceding the 1989 revolution as well as afterwards. Table 2 shows that there is also substantial variation in the change in all variables across regions. For each region, we take the average of a variable over the pre-1989 and post-1989 years, and compute the percentage change. Each row in the table reports the summary statistics for the percentage change. For example, while the conditional probability of conviction for robbery fell by $22.4 \%$ on average, there is a region (Central Bohemia) where it has fallen by a mere $10.3 \%$ and a region (North Bohemia) where it has fallen by as much as 37\%. This variation across regions provides an important source of identification.

Figure 1 shows the trends in crime rates for each crime category. The year of the regime change (1989) is highlighted. The murder rate has increased from approximately 1 murder per 100,000 to almost 3. The rate of robberies has more than quadrupled, while the rate of thefts has increased more than 10 times. Moreover, the sharp drop in thefts after 1994 should most likely be attributed to a change in reporting methodology rather than to any actual decline. Rapes appear to be the only crime category for which the number of offenses, after the initial jump, has returned back to the pre-1989 levels.

Figure 2 shows the trend in our measure of probability that an offender is charged. With the exception of murder, this probability has substantially decreased in the first years of democracy and then rebounded somewhat but still remains well below the pre-1989 levels. For example, while on average $79 \%$ of robbers were brought to court before 1989, only $54 \%$ were afterwards. This decline in police productivity is equally pronounced for thefts, where the probability of being charged declined from $33 \%$ to $19 \%$. It is worth noting that the declines in probability are much smaller than the increases in the number of offenses; therefore, the police catch far more offenders than they did before.

Figure 3 shows what has been happening inside the courtroom and demonstrates that the courts indeed got "softer" in convicting offenders. Under the communist 
judiciary, people charged with crime faced near-certainty of being found guilty specifically, $96 \%, 77 \%$, and $83 \%$ of people charged with murder, robbery, and theft, respectively, were convicted. After the revolution, these probabilities dropped to 72 , 61 , and 55 percent.

Finally, figure 4 demonstrates the courts' proclivity to use prison as a form of punishment. With the exception of murders, we can see that the democratic reforms have initiated a gradual decline in the use of prisons. For example, only $30 \%$ of convicted thieves were sent to prison in the year 2000, while $59 \%$ were in 1988. Again, from the data at hand we cannot say how much of this decline was due to the judges' discretion or to legislative changes mentioned in section 2 that encouraged the use of non-prison punishments.

\section{Estimates}

\subsection{Static framework}

We estimate the relationship between deterrence and crime in both a static and a dynamic framework. The static model is a fixed effects specification, similar to Cornwell and Trumbull (1994), Lott (1998), or Levitt (1998)

$$
\log Y_{i j t}=\beta_{i}^{A} \log P_{i j t}^{A}+\beta_{i}^{C} \log P_{i j t}^{C}+\beta_{i}^{F} \log F_{i j t}+\beta_{i}^{X} X_{j t}+\lambda_{i j}+\lambda_{i t}+\epsilon_{i j t}
$$

The subscripts $i, j$ and $t$ denote the crime category, region, and year, $Y$ denotes the crime rate, and $X$ denotes a vector of socioeconomic variables. ${ }^{31}$ Variables $\lambda_{i j}$ and $\lambda_{i t}$ denote region and year fixed effects. Given the fact that there was no visible trend in crime rates during the pre-1989 years, we restrict the year effects to be zero for all years until 1989. The estimated year fixed effects for the post- 1989 years are

\footnotetext{
${ }^{31}$ Note that we do not include the number of policemen among the explanatory variables. According to the economic model of crime, the number of policemen should not affect the number of offenses except through its effect on $P^{A}$ and $P^{C}$.
} 
of interest themselves - they have the interpretation of an average (across regions) log points increase in the crime rate that is not accounted for by the change in the observable variables.

It is likely that unobservable shocks $\epsilon_{i j t}$ are correlated across crime categories; therefore, the seemingly unrelated regressions framework is appropriate for estimating equation 1. The estimates are presented in Table 3. All coefficients on the probabilities of being charged and convicted have the expected negative sign. Also, for all crime categories, the coefficient on at least one of the probabilities is statistically significant, and both of them are statistically significant for robberies, thefts, and failure to support. ${ }^{32}$

There are two concerns with the basic SUR specification. One, the SUR estimates of the coefficients on $P^{A}$ would be biased if the number of offenses is measured with error, which is likely due to underreporting. ${ }^{33}$ Since the number of offenses enters the estimating equation on the left-hand side as well as in the denominator of $P^{A}$, a measurement error in the number of offenses (unless it is a constant fraction of actual offenses) generates a division bias that drives the estimates towards $-1 .^{34}$ Second, the contemporaneous values $P_{i j t}^{A}, P_{i j t}^{C}$, and $F_{i j t}$ need not be the appropriate measures of deterrence as perceived by potential offenders. Such specification implicitly assumes that offenders have rational expectations about the current level of deterrence. However, it has been documented that individuals have highly different perceptions about the probability of punishment, and they base them mostly on their and their peers' past experiences. ${ }^{35}$ We address both of these issues by replac-

\footnotetext{
${ }^{32}$ The statistic for the Breusch-Pagan test for independent equations is 80.7 , therefore we reject the hypothesis of no correlation of error terms across equations.

${ }^{33}$ The degree of underreporting can be inferred from the victimization survey conducted in the city of Prague in 2000 as a part of a wider International Crime Victimization Survey organized by United Nations Interregional Crime and Justice Research Institute in an effort to collect internationally comparable crime data. The survey showed that $96 \%$ of car thefts, $73 \%$ of bicycle thefts, $68 \%$ of burglaries, $46 \%$ of robberies and $41 \%$ of small thefts of personal property are reported to police.

${ }^{34}$ Since the first victimization survey in the Czech Republic was conducted in 1992, one is left to speculate about how the degree of underreporting changed under democracy. For example, if people report a theft because reporting may increase the chances of getting the stolen object back, the incentive to report weakens when the probability of arrest and conviction falls.

${ }^{35}$ Sah (1991) summarizes surveys on this topic.
} 
ing $P_{i j t}^{A}, P_{i j t}^{C}$, and $F_{i j t}$ with their one-year lags. Given the abrupt changes in the number of offenses and the fraction of offenders punished during the early 1990's, it may be more plausible to assume that offenders behave "as if" they had adaptive expectations, i.e. they base their decision to commit crime on deterrence observed last year. Since the lagged value of $P^{A}$ does not contain the number of offenses in the denominator, this specification should also remove the division bias.

The results are reported in Table 4 . Compared to the specification with contemporaneous values of the deterrence variables, the estimates of $\beta_{i}^{A}$ and $\beta_{i}^{C}$ are smaller in absolute values for all crime categories. The fact that the estimate of $\beta_{i}^{A}$ is smaller could be explained as evidence of removal of the division bias. The fact that estimates of both $\beta_{i}^{A}$ and $\beta_{i}^{C}$ are smaller opens up a possible explanation that the offenders do in fact have rational expectations, and therefore the number of offenses is correlated more strongly with the current rather than lagged level of deterrence. On the other hand, the estimates of the deterrent effect of expected punishment have the predicted negative sign (with the exception of rape) and are statistically significant for theft, failure to support, and injury in the specification with lagged values while they are generally smaller and actually positive for three crime categories in the specification with contemporaneous values. ${ }^{36}$

The estimated deterrence effects are of similar magnitude to those found in similar studies using U.S. or international data, at least for robbery and theft. The estimated elasticities of the crime rate with respect to the probability of being charged

\footnotetext{
${ }^{36} \mathrm{We}$ also attempted to eliminate the division bias by instrumenting the probability of being charged with $P^{A \mid I}$, the probability of being charged conditional on being investigated. The instrument is obviously correlated with the regressor since they have a common denominator. If the probability that a person already investigated for a crime is eventually charged is uncorrelated with the measurement error in the number of offenses, $P^{A \mid I}$ is indeed a valid instrument. This would be the case if $P^{A \mid I}$ is a policy variable chosen independently of the true or reported number of offenses; for example, if carrying the case from identifying an offender to charging him at the court is largely an administrative matter and the success of the process would not depend on the total caseload. With the exception of theft, instrumenting for $P^{A}$ does reduce the estimates of $\beta^{A}$ (from -0.81 to -0.31 for robberies, from -0.52 to -0.29 for failure to support etc.), with little effect on the estimates of $\beta^{C}$. For theft, the IV estimate of $\beta_{i}^{A}(-1.12)$ is surprisingly greater than the SUR estimate, even though the division bias problem should be most pronounced for theft due to the highest degree of underreporting. For this reason, we prefer the basic SUR specification. (Detailed IV results are available upon request.)
} 
are -0.42 (robbery) and -0.51 (theft) while the elasticities with respect to the conditional probability of being convicted are -0.18 (robbery) and -0.11 (theft). For comparison, Eide (1999) reports that the median estimate (out of 118 studies surveyed) of the elasticity of crime rate with respect to various measures of the probability of punishment was -0.7 . The study that is probably closest to ours in terms of choice of explanatory variables and estimation techniques (Cornwell and Trumbull $[1994]^{37}$ ) finds elasticities of -0.36 (with respect to probability of arrest) and -0.28 (with respect to probability of conviction). Our estimated deterrence effects are larger for robbery, theft, and failure to support than for murder, rape, and injury. This gives additional confidence in the reliability of the estimates, since one would indeed expect the "passion crimes" like murder and rape to be less sensitive to deterrence than theft and robbery, which are presumably more driven by the rational calculation of costs and benefits.

The implicit assumption behind equation 1 is that the relationship between crime rates and deterrence did not change as the country switched from the totalitarian regime to democracy. Of course, the enormous political, economic, and legal changes that the Czech Republic underwent just during the few months following the 1989 Revolution could have changed that relationship. We investigate the presence of a structural break in the data by estimating the same models as in Tables 3 and 4 with each variable also interacted with a dummy variable equal to 1 for all years after $1989^{38}$, and testing the null hypothesis that the coefficients on the interaction variables are jointly equal to zero. We perform the F-test separately for the deterrence and socioeconomic variables. Tables 5 and 6 show the results. There is virtually no evidence of a structural break in deterrence. In the specification with contemporaneous values of deterrence variables, the null is rejected only for failure

\footnotetext{
${ }^{37}$ They test the economic model of crime on a panel of North Carolina counties. The main focus of their paper is to demonstrate how controlling for unobserved fixed effects affects the estimated deterrent effects in comparison to estimates obtained from cross-sectional data, which were prevalently used prior to their study. Their dependent variable is the ratio of FBI index crimes, and their deterrence variables include the probability of arrest, conviction, imprisonment, and the average prison length.

${ }^{38}$ Note that there is no interaction on the unemployment variable because measured unemployment was zero until 1989.
} 
to support and rape, although in the case of rape there is rather a strange structural break when the elasticity of crime rate with respect to $P^{A}$ is positive and significant $(+0.52)$, and democracy significantly reduces this elasticity by 0.771 . In the specification with lagged deterrence variables, the null hypothesis of no structural break in deterrence cannot be rejected for any crime category, although this could be due to the fact that coefficients on the non-interacted terms are also smaller and have a larger variance. The results do show, however, a structural break in socioeconomic variables for theft, failure to support, rape, and injury. This gives us additional confidence that our coefficients on deterrence are capturing deterrence rather than unobservable factors that are correlated with deterrence. Since there is a structural break in observable socioeconomic variables, one would expect that there is also a structural break in the unobservable variables that, if correlated with deterrence, would cause a bias in the estimates. But in that case the structural break in unobservable variables should generate a structural break in deterrence variables, too. Given that we do not observe one, the presence of unobservables is probably not empirically important enough to affect the estimates of deterrence effects.

\subsection{Dynamic framework}

The dynamic version of the model attempts to capture the idea that "more crime breeds more crime" ${ }^{39}$ by endogenizing the probability of punishment and the size of the police force. The main idea, already implicitly contained in Becker's (1968) seminal paper, is that holding the enforcement resources fixed, an exogenous increase in the number of offenses reduces the probability of punishment. Committing crime therefore imposes a positive externality on all other offenders. If they base their choice of how many offenses to commit on the observed ex-post probability of punishment last year, then an exogenous increase in crime rate last year will increase the crime rate this year even further. The enforcement resources will adjust too, since an increase in crime this year will trigger the public's demand for higher

\footnotetext{
${ }^{39}$ Theoretically modeled in Sah (1991) and Glaeser et al. (1996).
} 
enforcement resources next year. This process can be described by three equations:

$$
\begin{aligned}
\log Y_{i j t} & =\beta_{i}^{A} \log P_{i j t-1}^{A}+\beta_{i}^{C} \log P_{i j t-1}^{C}+\beta_{i}^{F} \log F_{i j t-1}+\beta_{i}^{X} \log X_{j t}+\lambda_{i j}^{Y}+\lambda_{i t}^{Y}+\epsilon_{i j t}^{Y}, \\
\log P_{i j t-1}^{A} & =\gamma_{i}^{E} \log E_{j t-1}+\gamma_{i}^{Y} \log Y_{i j t-1}+\gamma_{i}^{Z} \log Z_{j t-1}^{P}+\lambda_{i j}^{P}+\lambda_{i t}^{P}+\epsilon_{i j t}^{P}, \forall i \\
\log E_{j t-1} & =\delta^{E} \log E_{j t-2}+\sum_{i} \delta_{i}^{Y} \log Y_{i j t-2}+\delta^{Z} \log Z_{j t-1}^{E}+\lambda_{i j}^{E}+\epsilon_{i j t}^{E}
\end{aligned}
$$

Equation 2 is the "supply-of-offenses" equation, expressing the number of offenses that offenders choose to commit as a function of deterrence in the previous year, socioeconomic variables in the current year, and the region and year fixed effects. Equation 3 endogenizes $P^{A}$ and can be interpreted as the production function of police. The "output" of police is the share of offenders charged for an offense in year $t-1$, and the inputs are enforcement resources $E_{j}$ in year $t-1$ (measured by the number of policemen per 100,000 inhabitants), the number of offenses $Y_{i j}$ in that year, and socioeconomic variables $Z^{P}$ that are a subset of the $X^{\prime} s$ in the supply of offenses equation. $^{40}$ The predicted sign of $\gamma^{E}$ is positive and of $\gamma^{Y}$ negative. We do not model the production function of courts since we do not have appropriate measures of courts' inputs. Therefore $P_{i j t}^{C}$ is treated as exogenous. Last, the size of the police force is also endogenized in the "demand for police" equation (4), where the lagged crime rates affect the number of policemen next year. Since the number of policemen tends to be rather stable even though crime rates highly fluctuate ${ }^{41}$, a one-year-lag of the number of policemen is also included among the explanatory variables. ${ }^{42}$ The socioeconomic variable $Z_{j t-1}^{E}$ that enters the supply of police equation is the average real wage in the public sector, since we would predict that fewer policemen will be employed if the government has to pay them a higher wage.

\footnotetext{
${ }^{40}$ We included the share of population aged 20 to 29 as the socioeconomic variable that affects the output of police, the justification being that as there are more potential offenders, the police has to spread its effort to identify and apprehend a particular offender over a larger group.

${ }^{41}$ In our data, the average year-to-year change in the number of policemen in a region is 2.6 percent with a standard deviation of 5.2 percent. In contrast, the average (unweighted) year-toyear change in the crime rate is 28 percent with a standard deviation of 98 percent.

${ }^{42}$ This specification for the demand for police equation is essentially identical to Ehrlich (1973).
} 
The system of 13 equations (2)-(4) is estimated by three-stage least squares. ${ }^{43}$ The results are shown in Table 7 . Similarly to previous estimates, the model shows no deterrence effect for murders or rape, but it does show a fairly strong deterrence effect of the probability of being charged and the length of prison punishment for robberies, thefts, failure to support, and intentional injury. The elasticity of crime rate with respect to the probability of being charged is -0.51 for robbery, -0.70 for thefts, -1.48 for failure to support, and -0.54 for intentional injury. In absolute value, the 3SLS estimates of deterrent effects are greater than the simple SUR estimates with lagged deterrence variables (Table 4). The expected length of a prison sentence has a statistically significant effect on theft, failure to support, and intentional injury. For these crime categories, the elasticities with respect to the length of a prison sentence are smaller than the elasticities with respect to the probability of being charged, which conforms to Ehrlich's (1975) theoretical ordering of elasticities. However, the magnitudes of the deterrent effect of the probability of conviction contradict this theoretical ordering, since they are smaller than the elasticities with respect to the length of punishment, and they are statistically significant only for failure to support. A strange feature of the results is that, contrary to what the theory predicts, the share of population aged 20-29 has unexpectedly a negative, and rather large effect on the crime rate for 3 out of 6 crime categories.

The estimated parameters of the police productivity equations are generally quite plausible. A one-percent increase in the number of policemen increases the probability of being charged by 0.52 percent for robberies and 0.39 percent for thefts. For murders, the estimate is negative and not significantly different from zero, which is somewhat surprising given that in the raw data, the ratio of suspects charged with murder to the number of murders actually slightly increased during the 1990s, and the number of policemen was also rising during that period. As expected, the

\footnotetext{
${ }^{43}$ We acknowledge that since the right-hand side of the supply of police equation contains a lagged dependent variable, the strict exogeneity assumption fails, and the consistent estimation technique would first remove the fixed effects by first differencing and then use lagged first differences in lagged right-hand side variables as instruments (Wooldridge [2002], pp.299-307). We did try this approach; however, it produced implausible estimates (negative estimate of $\delta^{E}$, very large standard errors), presumably because of a rather small sample size.
} 
number of offenses negatively affects the probability of being charged for all crime categories except murders.

Finally, the "demand for police" equation shows a large persistence in the size of the police force (the coefficient on the lag number of policemen is 0.86) and does not provide strong evidence on the adjustment of police to the previous year's crime rates - none of the coefficients on lagged number of murders, robberies, or thefts are statistically significant and only the latter two have the predicted positive sign. ${ }^{44}$

Additional evidence that our coefficients on deterrence variables indeed capture deterrence and not other factors can be inferred from the evolution of the estimated year fixed effects, plotted in Figure 5 with their $95 \%$ confidence intervals. The fixed effect for 1989 is normalized to zero, thus the fixed effects for subsequent years show an (average across regions) increase in crime rates since 1989 that the model fails to explain. The fit of the model is disappointing for murders and failure to support, since these crimes were rising steadily throughout the 1990's, and the year dummies simply track this trend. For thefts, the year fixed effects jump up sharply in 1990, and then stay flat. ${ }^{45}$ However, the theft rate in all years after 1990 is substantially larger than in 1990. We interpret such evolution of year fixed effects that whatever unobservable factors associated with democracy did contribute to the growth in thefts, they fully materialized already in 1990 while the subsequent growth in thefts was driven by weaker deterrence. In other words, with the exception of 1990, the number of thefts can be explained by changes in deterrence and socioeconomic variables. The same argument applies to robbery, where the year fixed effects also stay flat after reaching the peak in 1991. For intentional injury, the year fixed effects

\footnotetext{
${ }^{44} \mathrm{We}$ also checked whether the presence of a lagged crime rate in the productivity of police equation possibly induces some spurious correlation that would bias the estimated deterrent effects. After removing it from the system, the coefficients on $P^{A}$ for robberies and thefts are slightly smaller ( -0.51 and -0.49 , respectively), and for injury the coefficient on $P^{A}$ actually becomes positive. In the productivity of police equation, the effect of police on $P^{A}$ is greater than in the specification with lagged offenses ( 0.75 for robberies, 0.74 for thefts). This indicates that the crime rate is indeed a relevant "input" into the police production function and makes the specification with a lagged crime rate preferable.

${ }^{45}$ There is no statistically significant difference between coefficients on the year dummy representing 1990 and the year dummies representing all subsequent years.
} 
are actually negative and statistically not different from zero for most years. The substantial increase in the rate of intentional injuries is thus entirely explained by weaker deterrence and changes in socioeconomic variables.

\subsection{How much can deterrence explain?}

With these results at hand, a natural question to ask is: What would the crime rates be if the democratic government somehow managed to keep the level of deterrence as high as the communist one? We use the coefficients from Table 7 and predict the crime rates under the assumption that $P_{i j t}^{A}, P_{i j t}^{C}$, and $F_{i j t}$ would stay at the same level as in 1989 for all the following years while the socioeconomic variables and the year fixed effects would evolve as they did. The evolution of the predicted and actual crime rates aggregated at the national level is presented in Figure 6. Since the estimates do not show a strong deterrence effect on murders and rapes, it is not surprising that stronger deterrence would not change the number of these offenses. In the model, all changes in murders and rapes are picked up by the year dummies. The model predicts, however, that the number of robberies, thefts, intentional injuries, and, to a lesser extent, failures to support, would be substantially lower if deterrence were kept at the 1989 level. For example, the robbery rate was 16.8 in 1989 and 45.8 in 2000 . Had deterrence stayed the same, the model predicts that the robbery rate would have been only 30 .

Table 8 shows how much of the change in crime rates between 1989 and 2000 is accounted for by the change in deterrence. Our estimates imply that deterrence accounts for $54 \%$ of the increase in robberies, $61 \%$ of the increase in thefts and $68 \%$ of the increase in intentional injuries.

These numbers are very similar to Lin (2003) who also finds that deterrence is unable to explain the cross-country differences in crime rates between democracies and non-democracies for serious violent crimes such as murders and rapes. He also finds that weaker deterrence accounts for about 40 to $50 \%$ of the differences for 
robberies and thefts, which is somewhat smaller than our findings. This can be explained in part by the difference in estimated deterrence effects (Lin's estimates of deterrence effects lie between -0.17 and -0.28 , generally smaller than most of our estimates), and in part by smaller variation in deterrence. For example, in Lin's dataset, the clearance rate for robberies in countries classified as "high democracy" is on average 18 percent below that in countries classified as "low democracy", while in the Czech Republic's case, the probability of being charged has been on average 32 percent below what its level was during the communist period.

\section{Conclusions}

Whether deterrence works has been the central question in the economics of crime since the very beginning of the field. The collapse of communism in the Czech Republic, and the very sharp decline in all measures of deterrence that immediately followed, provided an opportunity to gain new evidence on this question. Exploiting region-level variation in the levels and changes in deterrence, we obtained statistically and economically significant deterrence effects for robberies, thefts and burglaries, failure to support, and intentional injuries, but insignificant deterrence effects for murders and rapes. The results are generally robust to alternative specifications, and we presented evidence that they indeed reflect a causal relationship between deterrence and crime rather than other factors through which democracy led to higher crime. The results also concur with the earlier literature showing that democracies have different patterns of crime and that a large part of the difference is attributable to weaker deterrence.

\section{References}

[1] Andrienko, Yuri and Louise Shelley: Crime, Violence and Conflict: Russia Case Study. CEFIR working paper 2003. 
[2] Becker, Gary S.: Crime and Punishment: An Economic Approach, Journal of Political Economy, Vol. 76, No.2, March 1968, pp. 169-217.

[3] Block, Michael and Vernon E. Gerety: Some Experimental Evidence on Differences between Student and Prisoner Reactions to Monetary Penalties and Risk, Journal of Legal Studies 24, January 1995, pp. 123-38.

[4] Cejp, Martin: Organizovany zlocin v Ceske republice v letech 1993-2002, in: Kriminalita v roce 2002, Institut pro kriminologii a socialni prevenci, Praha 2003.

[5] Cornwell, Christopher and William N. Trumbull: Estimating the Economic Model of Crime with Panel Data, The Review of Economics and Statistics, Vol. 76, No.2, May 1994, pp. 360-366.

[6] Ehrlich, Isaac.: Participation in Illegitimate Activities: A Theoretical and Empirical Investigation, The Journal of Political Economy, Vol. 81, No.3, May 1973, pp. 521-565.

[7] Ehrlich, Isaac: The Deterrent Effect of Capital Punishment: A Question of Life and Death, American Economic Review, Vol. 65, No. 3, June 1975, pp. 397-417.

[8] Eide, Erling: Economics of Criminal Behavior, in Bouckaert, Boudewijn and De Geest, Gerrit (eds.): Encyclopedia of Law and Economics, Volume V, Edward Elgar, Chetenham 2000.

[9] Gould, Eric D., Bruce A. Weinberg, and David B. Mustard: Crime Rates and Local Labor Market Opportunities in the United States: 1979-1997, The Review of Economics and Statistics, Vol. 84, No. 1, February 2002, pp. 45-61.

[10] Kezdi, Gabor: Robust Standard Error Estimation in Fixed-Effects Panel Models, University of Michigan working paper, mimeo 2001.

[11] Lee, David S., and Justin McCrary: Crime, Punishment, and Myopia, mimeo 2005. 
[12] Levitt, Steven D.: Using Electoral Cycles in Police Hiring to Estimate the Effect of Police on Crime, American Economic Review, Vol. 87, No. 3., June 1997, pp. 270-290.

[13] Levitt, Steven D.: Juvenile Crime and Punishment, Journal of Political Economy, Vol. 106, December 1998, pp. 1156-1185.

[14] Lin, Ming-Jen: Does Democracy Increase Crime? Evidence from International Data, working paper, National Taiwan University, 2003.

[15] Lott, John Jr.: More Guns, Less Crime, University of Chicago Press 1998.

[16] Martinkova, Milada: Mezinarodni vyzkum obeti trestne cinnost v Praze v roce 2000, Institut pro kriminologii a socialni prevenci, 2002.

[17] Sah, Raj: Social Osmosis and Patterns of Crime, Journal of Political Economy, Vol. 99, No. 61, 1991, pp. 1272-1295.

[18] Soares, Rodrigo R.: Development, Crime and Punishment: Accounting for the International Differences in Crime Rates, Journal of Development Economics, Vol. 73, Issue 1, February 2004, pp. 155-184.

[19] Taylor, John B.: Econometric Models of Criminal Behavior: A Review, in Heineke, John M. (ed.): Economic Model of Criminal Behavior, North-Holland Publishing, New York 1978.

[20] Tomin, Mikulas (ed): K nekterym pricinam vzestupu krmininality v roce 1990, Institut pro kriminologii a socialni prevenci, Praha 1991.

[21] Tucek et al: The Fluctuation of Public Opinion between Years 1990 and 1998, Sociological Papers No. 1, 1999.

[22] Vujtech et al: Ucinky transformace trestniho zakonodarstvi na stav kriminality a zvysovani efektivnosti justice ve vztahu k bezpecnosti obcanu CR v horizontu roku 2000, Institut pro kriminologii a socialni prevenci, Praha 2001. 
[23] Williams, James L. and Adele S. Serrins: Comparing Violent Crime in the Soviet Union and the United States: 1985-1990, Studies on Crime and Crime Prevention, Vol. 4, No.2, 1995, pp. 252-266.

[24] Witte, Ann D.: Estimating the Economic Model of Crime with Individual Data, Quarterly Journal of Economics, Vol. 94, February 1980, pp. 57-84.

[25] Wooldridge, Jeffrey M.: Econometric Analysis of Cross Section and Panel Data, MIT Press, Cambridge 2002. 


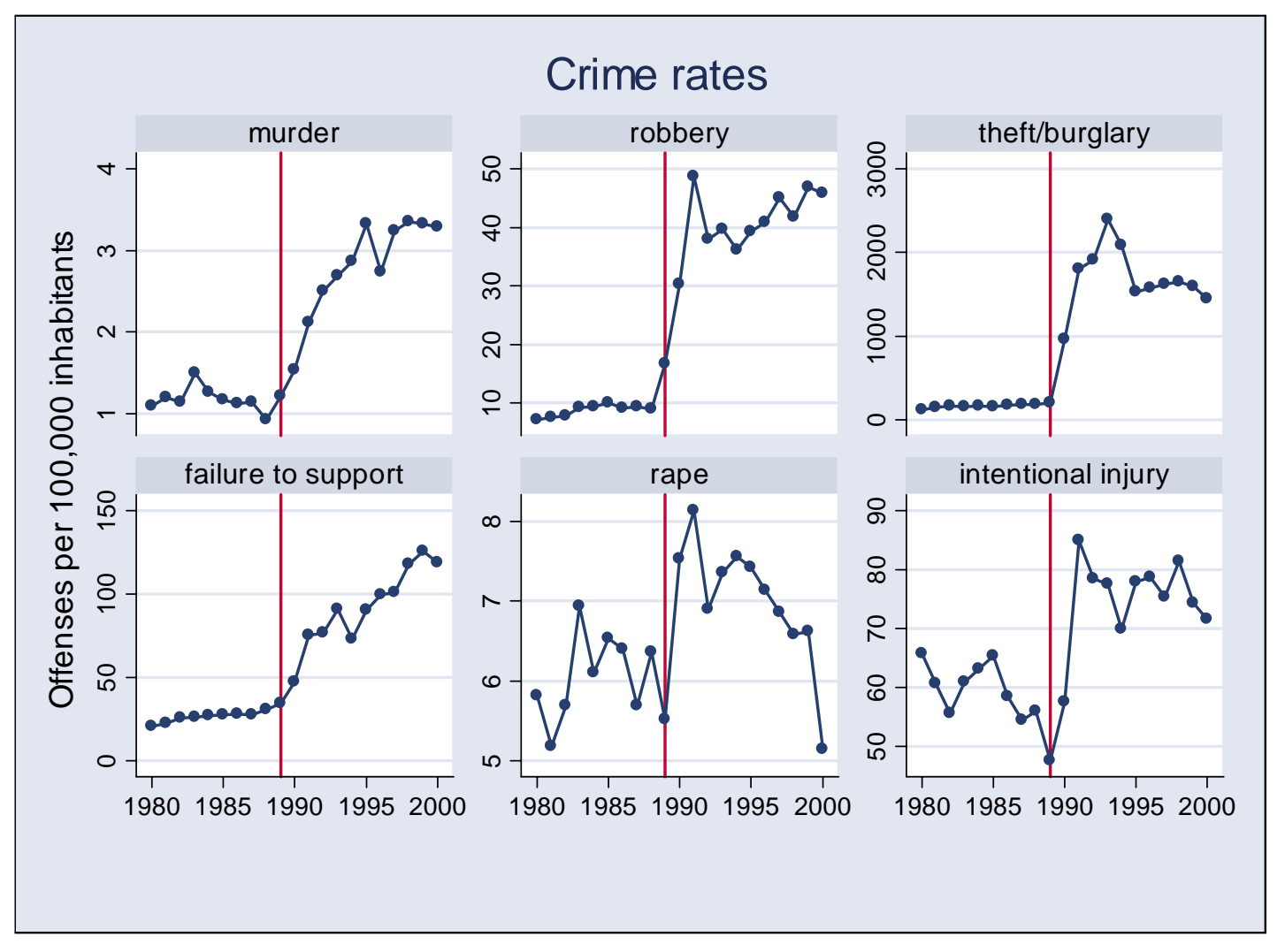

Figure 1: Crime rates 


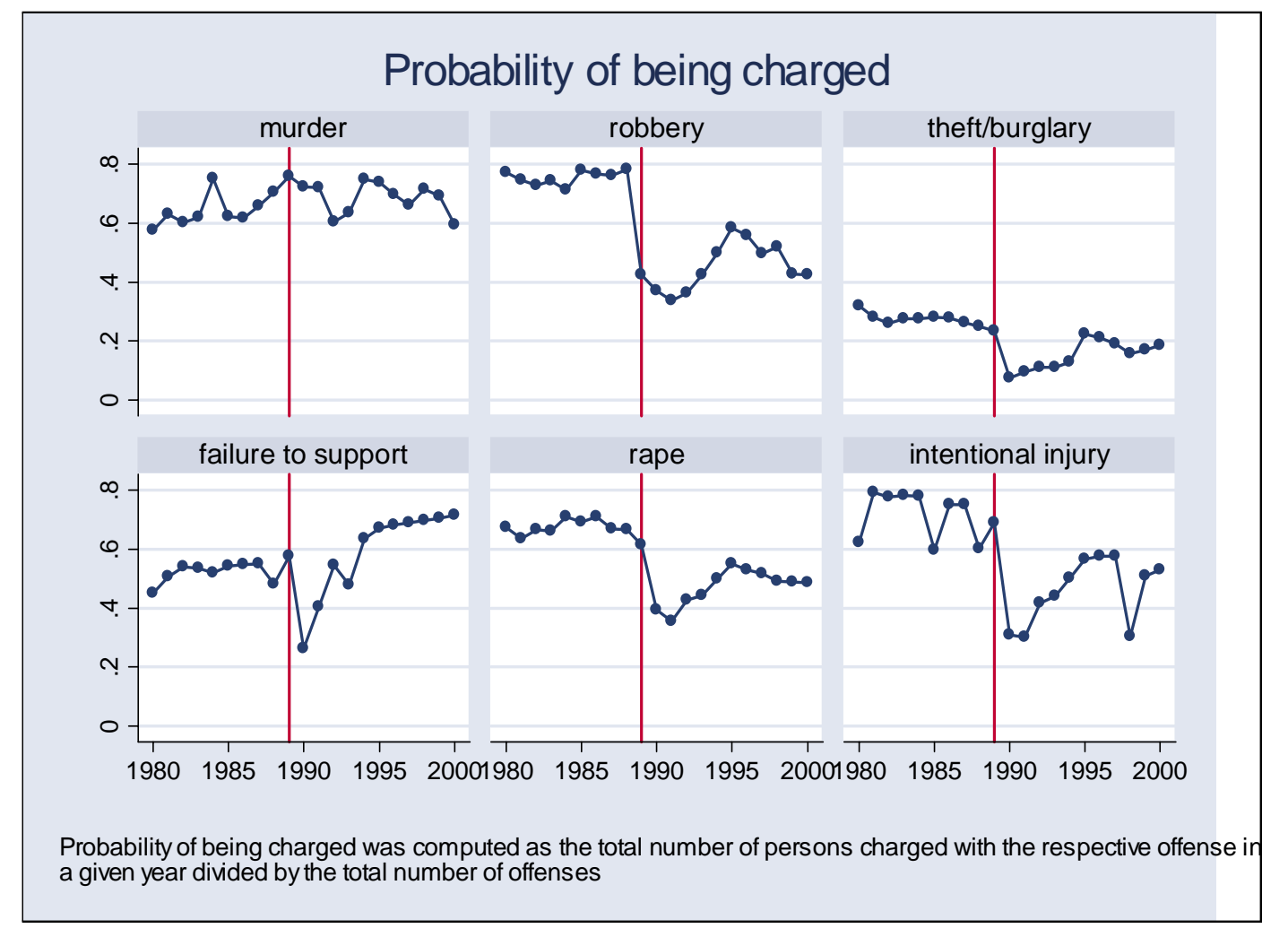

Figure 2: Probability of being charged 


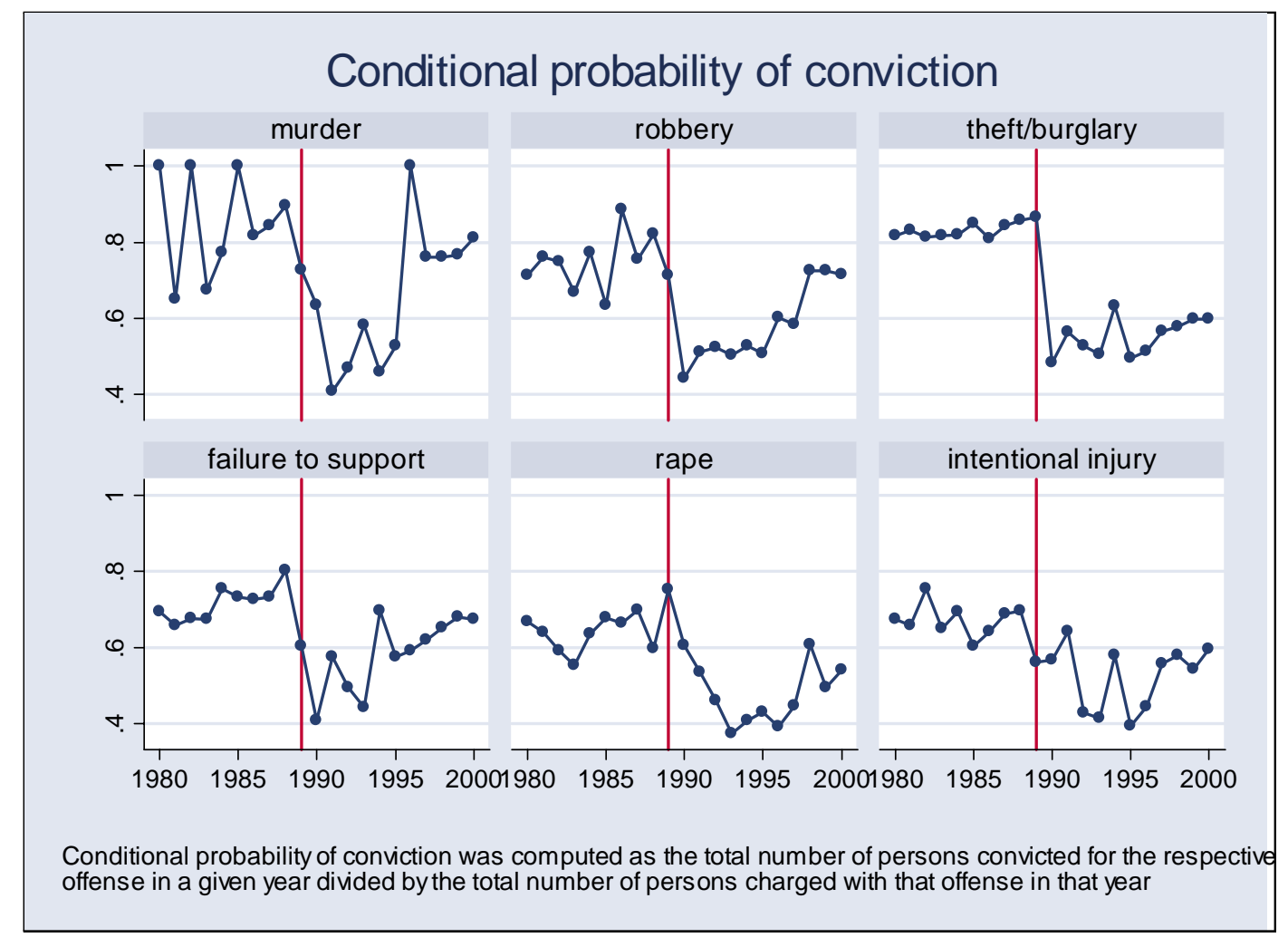

Figure 3: Conditional probability of conviction 


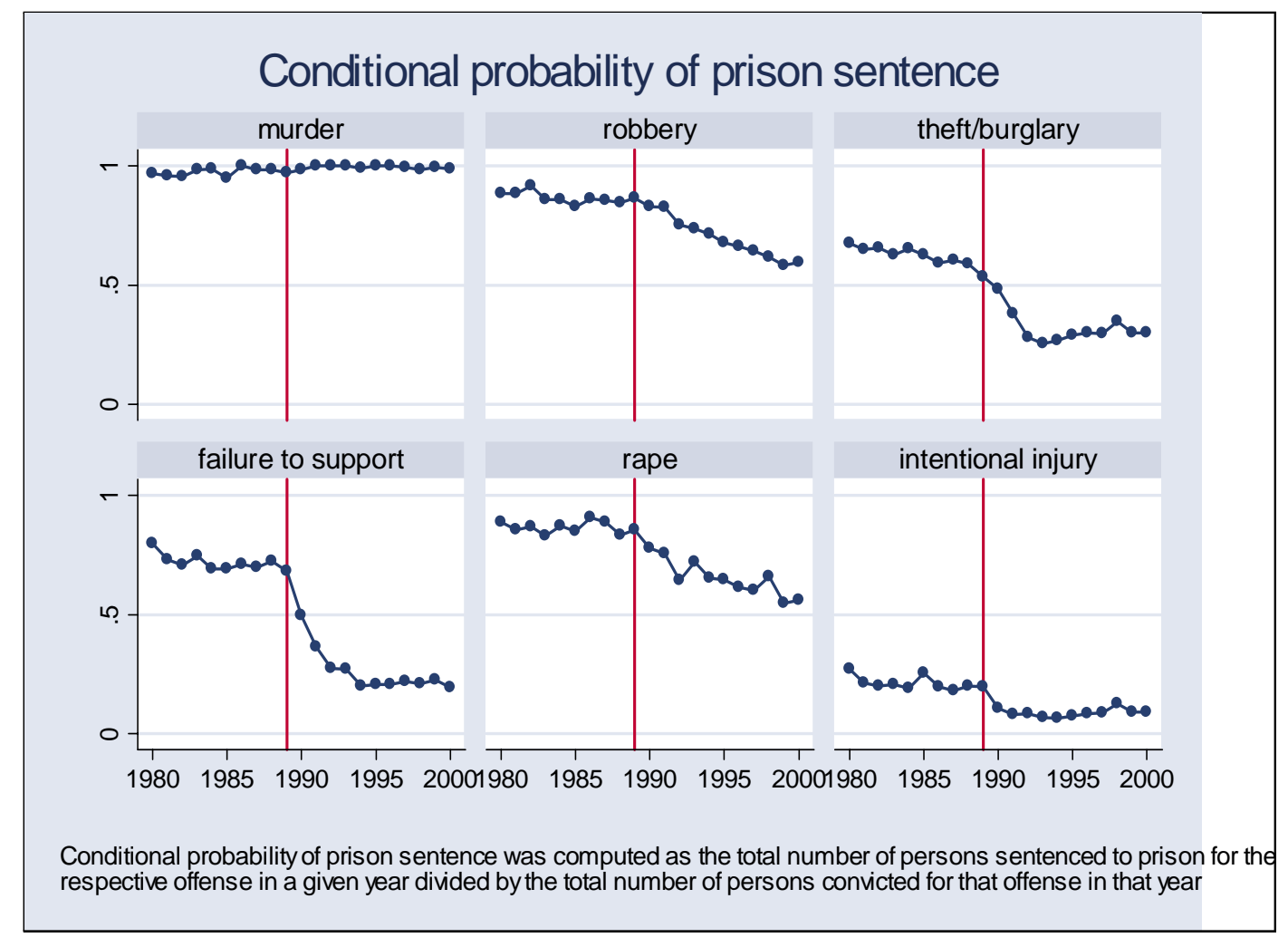

Figure 4: Conditional probability of prison sentence 


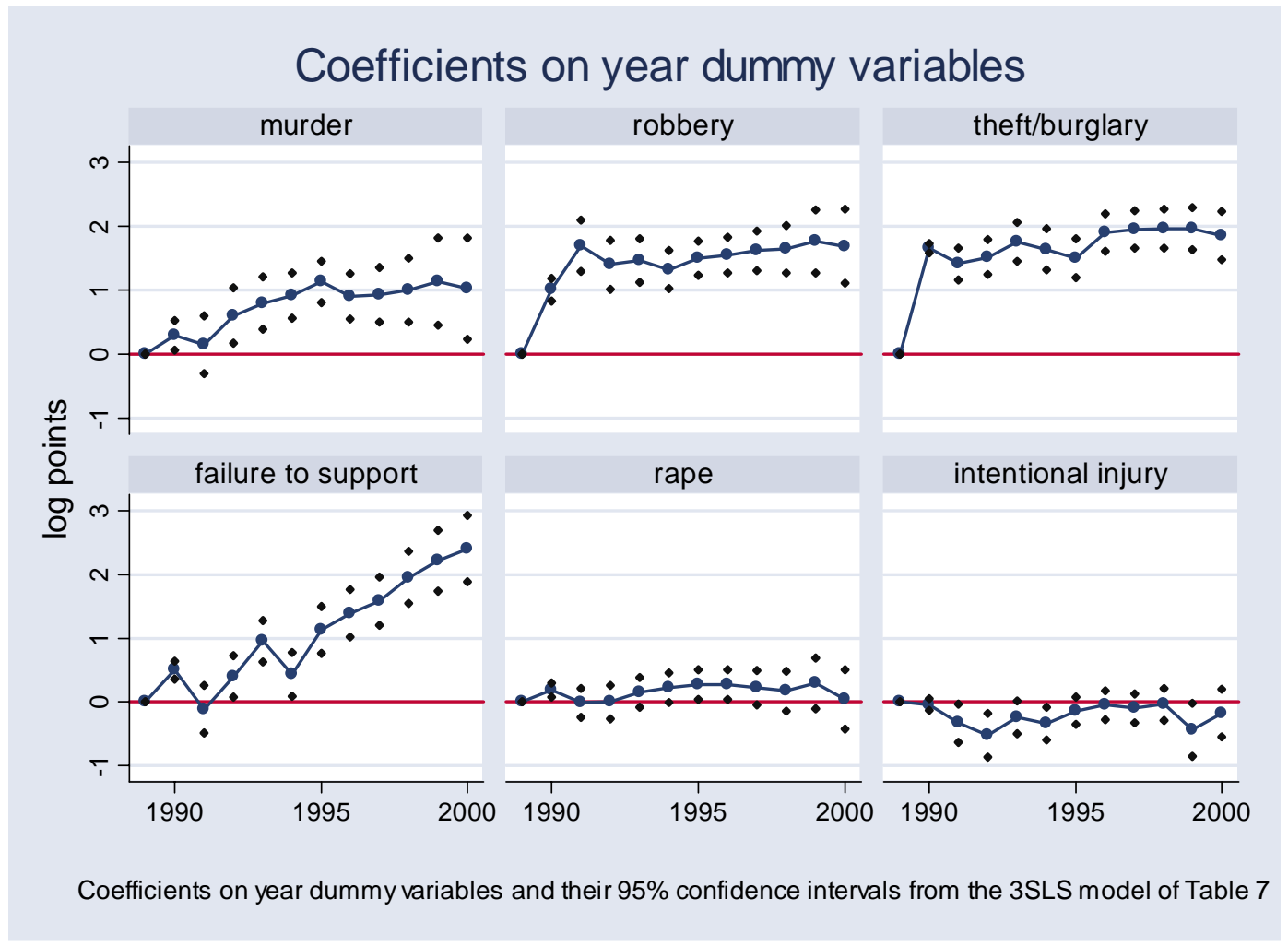

Figure 5: Coefficients on year dummy variables 
Crime rates: actual vs predicted under unchanged deterrence
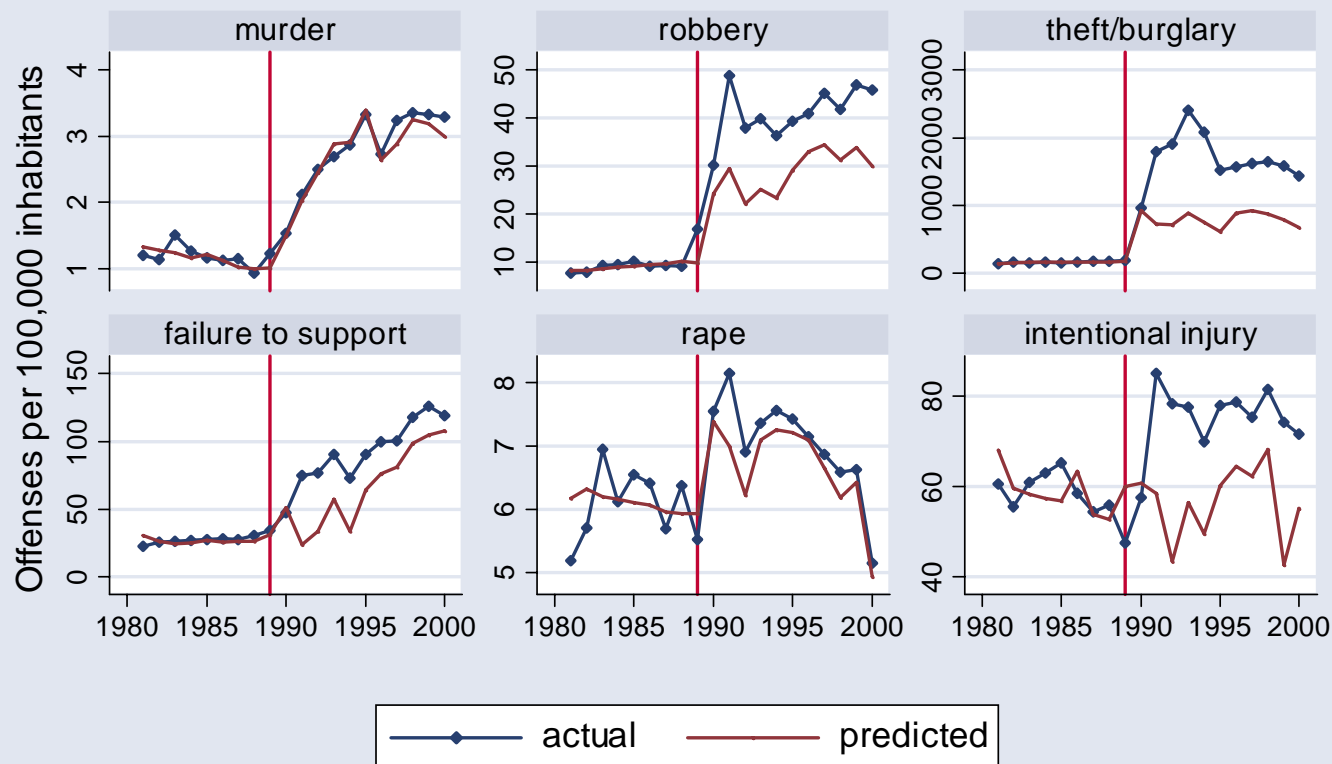

The predicted crime rates are national aggregates of the fitted values from the 3 SLS model of Table 7 . For the years after 1989, the probability of being charged, probability of conviction and the length of prison sentence are held at their 1989 levels.

Figure 6: Crime rates: actual versus predicted under unchanged deterrence 
Table 1

\section{Summary statistics}

Murder

Crime rate

Probability of being charged

Probability of conviction

Probability of prison sentence

Length of prison sentence

Robbery

Crime rate

Probability of being charged

Probability of conviction

Probability of prison sentence

Length of prison sentence

\section{Theft / burglary}

Crime rate

Probability of being charged

Probability of conviction

Probability of prison sentence

Length of prison sentence

Failure to support

Crime rate

Probability of being charged

Probability of conviction

Probability of prison sentence

Length of prison sentence

Rape

Crime rate

Probability of being charged

Probability of conviction

Probability of prison sentence

Length of prison sentence

Intentional injury

Crime rate

Probability of being charged

Probability of conviction

Probability of prison sentence

Length of prison sentence

Socio- economic variables

Share of population aged 20-29

Unemployment among men aged 20-

Average wage (1989 CZK)

Average wage in construction industr!

Average wage in financial services

Average wage in public sector

Policemen (per 100,000 people)

\begin{tabular}{cr}
\multicolumn{2}{c}{ Communism } \\
$\begin{array}{cr}\text { (years 1980- 1989) } \\
\text { mean } & \text { std. dev. } \\
1.21 & 0.60 \\
0.63 & 0.18 \\
0.98 & 0.62 \\
0.98 & 0.05 \\
132 & 33\end{array}$
\end{tabular}

$\begin{array}{rr}\text { mean } & \text { std. dev. } \\ 9.4 & 9.0 \\ 0.79 & 0.12 \\ 0.77 & 0.18 \\ 0.87 & 0.08 \\ 50.3 & 8.8\end{array}$

mean std. dev.

$\begin{array}{ll}163 & 127\end{array}$

$0.33 \quad 0.10$

$0.84 \quad 0.07$

$0.62 \quad 0.06$

$20.1 \quad 3.3$

mean std. dev.

$25 \quad 14$

$0.55 \quad 0.10$

$0.70 \quad 0.11$

$0.69 \quad 0.08$

12.4

mean

$\begin{array}{rr}6.0 & 2.1 \\ 0.69 & 0.11 \\ 0.67 & 0.16 \\ 0.86 & 0.08 \\ 51.2 & 7.6\end{array}$

mean std. dev.

$57 \quad 21$

$0.73 \quad 0.13$

$0.66 \quad 0.10$

$0.21 \quad 0.05$

$9.2 \quad 1.9$

mean std. dev.

$0.14 \quad 0.01$

$0.00 \quad 0.00$

$2990 \quad 142$

$3339 \quad 128$

$4989 \quad 298$

$3484 \quad 217$

239
Democracy

(years 1990-2000)

mean std. dev.

$2.84 \quad 1.32$

$0.68 \quad 0.17$

$0.71 \quad 0.38$

$0.99 \quad 0.03$

$127 \quad 25$

$\begin{array}{rr}\text { mean } & \text { std. dev. } \\ 41.3 & 31.1 \\ 0.54 & 0.17 \\ 0.59 & 0.15 \\ 0.70 & 0.10 \\ 48.9 & 5.2\end{array}$

mean std. dev.

$1697 \quad 1040$

$0.18 \quad 0.08$

$0.55 \quad 0.09$

$0.31 \quad 0.08$

$15.0 \quad 2.6$

mean std. dev.

$91 \quad 34$

$0.59 \quad 0.15$

$0.57 \quad 0.12$

$0.24 \quad 0.10$

$9.5 \quad 1.3$

mean std. dev.

$\begin{array}{ll}7.1 & 2.1\end{array}$

$0.48 \quad 0.11$

$0.50 \quad 0.19$

$0.65 \quad 0.16$

$56.2 \quad 12.2$

mean std. dev.

$72 \quad 30$

$0.49 \quad 0.15$

$0.51 \quad 0.11$

$0.09 \quad 0.04$

$12.4 \quad 4.4$

mean std. dev.

$0.15 \quad 0.01$

$4.64 \quad 3.40$

$2925 \quad 538$

$3133 \quad 448$

$4690 \quad 896$

$3265 \quad 459$

$344 \quad 85$ 
Table 2

\section{Between-region variation in a percentage change of a variable from pre-1989 to post-1989 period*}

Murder
Crime rate
Probability of being charged
Probability of conviction
Probability of prison sentence
Length of prison sentence

Robbery

Crime rate

Probability of being charged

Probability of conviction

Probability of prison sentence

Length of prison sentence

\section{Theft / burglary}

Crime rate

Probability of being charged

Probability of conviction

Probability of prison sentence

Length of prison sentence

\section{Failure to support}

Crime rate

Probability of being charged

Probability of conviction

Probability of prison sentence

Length of prison sentence

\section{Rape}

Crime rate

Probability of being charged

Probability of conviction

Probability of prison sentence

Length of prison sentence

\section{Intentional injury}

Crime rate

Probability of being charged

Probability of conviction

Probability of prison sentence

Length of prison sentence

\section{Socio-economic variables}

Share of population aged 20-29

Average wage (1989 CZK)

Average wage in construction indus

Average wage in financial services

Average wage in public sector

Policemen (per 100,000 people)

\begin{tabular}{rrrr} 
mean & std.dev. & \multicolumn{1}{c}{$\min$} & \multicolumn{1}{c}{$\max$} \\
142.4 & 50.5 & 67.4 & 199.3 \\
7.5 & 9.9 & -9.0 & 18.6 \\
-25.0 & 14.7 & -53.4 & -5.6 \\
1.5 & 0.9 & 0.0 & 2.9 \\
-2.7 & 9.7 & -14.9 & 11.2
\end{tabular}

341.4

$92.0 \quad 217.0$

449.6

$-32.3$

$12.2-56.1$

$-20.7$

$-22.4$

$-19.4$

$-36.8$

$4.3 \quad-25.0 \quad-13.6$

$-10.3$

$-2.2$

$7.9-11.9$

9.6

$\begin{array}{rrrr}1031.5 & 156.8 & 740.1 & 1200.2 \\ -45.4 & 5.0 & -51.4 & -39.2 \\ -34.1 & 6.0 & -42.7 & -22.7 \\ -49.3 & 8.1 & -55.5 & -30.6 \\ -24.4 & 10.0 & -37.9 & -4.7\end{array}$

341.1

146.5

662.6

7.7

$-17.7$

8.9

$-9.2$

17.6

$-29.6$

$-74.4$

$-6.2$

$-64.7$

$-32.1$

$-6.9$

20.2

$-29.9$

$-23.7$

$-24.5$

10.4

11.1

2.9

$-37.8$

$\begin{array}{lll}13.5 & -48.1 & -6.9\end{array}$

$\begin{array}{lll}5.6 & -33.3 \quad-15.0\end{array}$

$\begin{array}{lll}13.8 & -5.9 & 34.2\end{array}$

32.4

27.5

$16.9-0.2$

46.9

$-33.2$

$4.7 \quad-43.2$

$-28.5$

$-22.0$

$5.0 \quad-28.0$

$-14.5$

$-58.4$

$9.0 \quad-68.0$

$-46.1$

37.5

$21.2 \quad 10.5$

64.5

$\begin{array}{rrrr}8.8 & 4.1 & 4.1 & 17.4 \\ -2.4 & 7.3 & -8.8 & 16.1 \\ -7.5 & 7.6 & -12.8 & 12.1 \\ -6.3 & 7.2 & -10.3 & 12.5 \\ -6.4 & 4.1 & -9.9 & 3.6 \\ 43.4 & 12.4 & 17.8 & 63.2\end{array}$

* For each variable, we take the within-region average over years until 1989 and the years after 1989. For each region, we take the percentage difference between the post-1989 and pre-1989 average. The table shows a summary of this percentage difference across regions. 
Table 3

Results from seemingly unrelated regressions specification

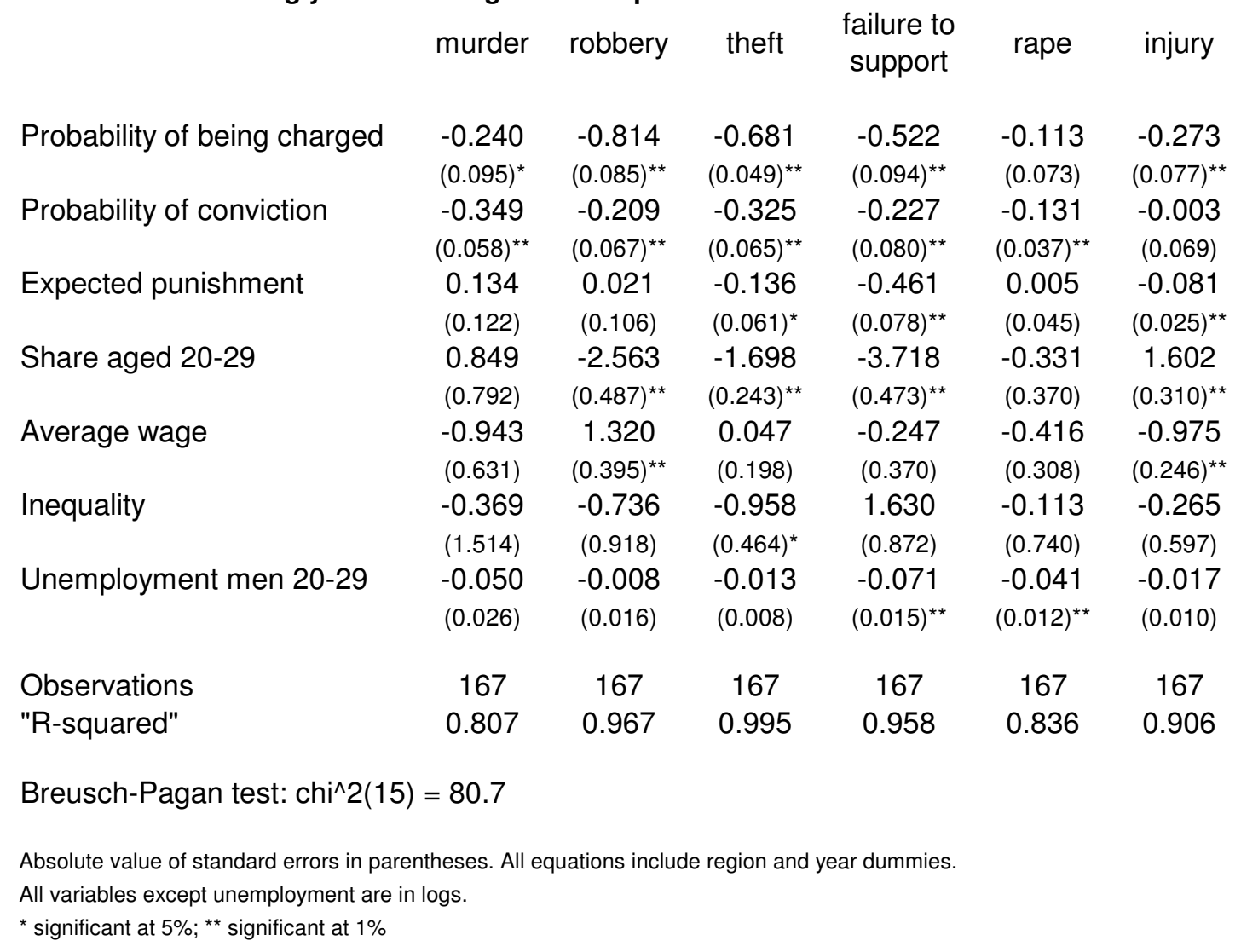


Table 4

Results from SUR specification with lagged deterrence variables

$\begin{array}{lcccccc} & \text { murder } & \text { robbery } & \text { theft } & \begin{array}{c}\text { failure to } \\ \text { support }\end{array} & \text { rape } & \text { injury } \\ & & & & & & \\ \text { Lag probability of being charged } & -0.089 & -0.419 & -0.507 & -0.403 & 0.032 & -0.032 \\ & (0.098) & (0.110)^{\star *} & (0.060)^{\star *} & (0.104)^{\star *} & (0.086) & (0.079) \\ \text { Lag probability of conviction } & -0.020 & -0.179 & -0.110 & -0.080 & 0.041 & -0.002 \\ & (0.060) & (0.084)^{\star} & (0.077) & (0.090) & (0.044) & (0.074) \\ \text { Lag punishment } & -0.088 & -0.172 & -0.299 & -0.511 & 0.010 & -0.073 \\ & (0.126) & (0.134) & (0.076)^{\star *} & (0.085)^{\star *} & (0.053) & (0.027)^{\star *} \\ \text { Share men aged 20-29 } & 2.929 & -2.351 & -1.480 & -3.486 & -0.547 & 1.275 \\ & (0.917)^{\star *} & (0.689)^{\star *} & (0.301)^{\star *} & (0.559)^{\star *} & (0.475) & (0.359)^{\star *} \\ \text { Average wage } & -1.918 & 1.848 & -0.225 & -0.509 & -0.528 & -0.934 \\ & (0.669)^{\star *} & (0.476)^{\star *} & (0.218) & (0.385) & (0.352) & (0.261)^{\star *} \\ \text { Inequality } & -0.931 & 0.063 & -0.910 & 1.414 & -0.665 & 0.270 \\ & (1.544) & (1.125) & (0.504) & (0.872) & (0.806) & (0.607) \\ \text { Unemployment } & -0.062 & -0.035 & -0.033 & -0.072 & -0.037 & -0.023 \\ & (0.026)^{\star} & (0.020) & (0.009)^{\star *} & (0.015)^{\star *} & (0.014)^{\star *} & (0.010)^{\star} \\ \text { Observations } & & & & & & \\ \text { "R-squared" } & 159 & 159 & 159 & 159 & 159 & 159 \\ & 0.799 & 0.950 & 0.994 & 0.957 & 0.794 & 0.905\end{array}$

Breusch-Pagan test:chi^2(15) $=51.0$

Absolute value of standard errors in parentheses. All equations include region and year dummies. All variables except unemployment are in logs.

${ }^{*}$ significant at $5 \%$; ${ }^{* *}$ significant at $1 \%$ 
Table 5

Test for structural break, SUR specification

\begin{tabular}{|c|c|c|c|c|c|c|}
\hline & murder & robbery & theft & $\begin{array}{c}\text { failure to } \\
\text { support }\end{array}$ & rape & injury \\
\hline \multirow[t]{2}{*}{ Probability of being charged } & -0.196 & -0.894 & -0.618 & -0.280 & 0.521 & -0.382 \\
\hline & $(0.130)$ & $(0.114)^{\star \star}$ & $(0.092)^{\star \star}$ & $(0.121)^{\star}$ & $(0.164)^{\star \star}$ & $(0.095)^{\star \star}$ \\
\hline \multirow{2}{*}{ interacted with democracy } & -0.048 & 0.269 & -0.103 & -0.217 & -0.771 & 0.175 \\
\hline & $(0.190)$ & $(0.166)$ & $(0.090)$ & $(0.187)$ & $(0.177)^{\star \star}$ & $(0.139)$ \\
\hline \multirow[t]{2}{*}{ Probability of conviction } & -0.404 & -0.183 & -0.379 & -0.148 & -0.132 & -0.046 \\
\hline & $(0.078)^{\star \star}$ & $(0.089)^{\star}$ & $(0.110)^{\star \star}$ & $(0.114)$ & $(0.066)^{\star}$ & $(0.094)$ \\
\hline \multirow[t]{2}{*}{ interacted with democracy } & 0.093 & -0.021 & 0.144 & 0.032 & -0.024 & 0.053 \\
\hline & $(0.121)$ & $(0.144)$ & $(0.123)$ & $(0.160)$ & $(0.078)$ & $(0.120)$ \\
\hline \multirow[t]{2}{*}{ Expected punishment } & 0.304 & 0.067 & 0.078 & 0.170 & -0.032 & -0.054 \\
\hline & $(0.154)^{\star}$ & $(0.143)$ & $(0.111)$ & $(0.164)$ & $(0.114)$ & $(0.073)$ \\
\hline \multirow[t]{2}{*}{ interacted with democracy } & -0.389 & -0.108 & -0.206 & -0.590 & 0.035 & -0.022 \\
\hline & $(0.265)$ & $(0.186)$ & $(0.127)$ & $(0.191)^{\star \star}$ & $(0.121)$ & $(0.078)$ \\
\hline \multirow[t]{2}{*}{ Share aged $20-29$} & 0.599 & -2.418 & -1.064 & -1.653 & -0.407 & 1.014 \\
\hline & $(0.868)$ & $(0.526)^{\star *}$ & $(0.248)^{\star *}$ & $(0.518)^{\star \star}$ & $(0.387)$ & $(0.324)^{\star *}$ \\
\hline \multirow[t]{2}{*}{ interacted with democracy } & -0.800 & -2.142 & 0.662 & 1.266 & 0.597 & -1.330 \\
\hline & (1.484) & $(0.913)^{\star}$ & $(0.607)$ & $(0.817)$ & $(0.714)$ & $(0.599)^{\star}$ \\
\hline \multirow[t]{2}{*}{ Average wage } & -2.123 & 1.566 & 2.084 & 3.455 & -0.218 & -2.889 \\
\hline & $(1.276)$ & $(0.790)^{*}$ & $(0.419)^{\star \star}$ & $(0.737)^{\star \star}$ & $(0.612)$ & $(0.544)^{\star \star}$ \\
\hline \multirow[t]{2}{*}{ interacted with democracy } & 0.931 & -0.027 & -1.828 & -3.361 & -0.467 & 1.845 \\
\hline & (1.191) & $(0.809)$ & $(0.466)^{* \star}$ & $(0.711)^{\star \star}$ & $(0.625)$ & $(0.539)^{\star \star}$ \\
\hline \multirow[t]{2}{*}{ Inequality measure } & -0.316 & -0.800 & -1.912 & -0.025 & -1.482 & -0.054 \\
\hline & $(2.010)$ & $(1.215)$ & $(0.563)^{\star \star}$ & $(1.005)$ & $(0.925)$ & $(0.797)$ \\
\hline \multirow[t]{2}{*}{ interacted with democracy } & -0.008 & 0.153 & 0.468 & 0.680 & 1.299 & 0.094 \\
\hline & $(1.144)$ & $(0.682)$ & $(0.322)$ & $(0.574)$ & $(0.513)^{\star}$ & $(0.437)$ \\
\hline \multirow[t]{2}{*}{ Unemployment } & -0.054 & -0.003 & 0.008 & -0.040 & -0.034 & -0.022 \\
\hline & $(0.029)$ & $(0.018)$ & $(0.008)$ & $(0.014)^{\star \star}$ & $(0.013)^{\star \star}$ & $(0.011)^{*}$ \\
\hline Observations & 167 & 167 & 167 & 167 & 167 & 167 \\
\hline R-squared & 0.811 & 0.968 & 0.996 & 0.970 & 0.860 & 0.916 \\
\hline \multicolumn{7}{|l|}{ Test for structural break: } \\
\hline Deterrence variables & 3.35 & 3.10 & 4.33 & 11.45 & 19.04 & 1.81 \\
\hline $\mathrm{P}>$ chi2 & 0.341 & 0.376 & 0.228 & 0.010 & 0.000 & 0.612 \\
\hline \multirow[t]{2}{*}{ Socio-econ variables } & 4.73 & 6.29 & 32.28 & 63.34 & 23.44 & 20.66 \\
\hline & 0.317 & 0.179 & 0.000 & 0.000 & 0.000 & 0.000 \\
\hline
\end{tabular}

Absolute value of standard errors in parentheses. All equations include region and year dummies.

All variables except unemployment are in logs.

${ }^{*}$ significant at $5 \%$; ${ }^{* *}$ significant at $1 \%$ 
Table 6

Test for structural break, SUR with lagged deterrence variables

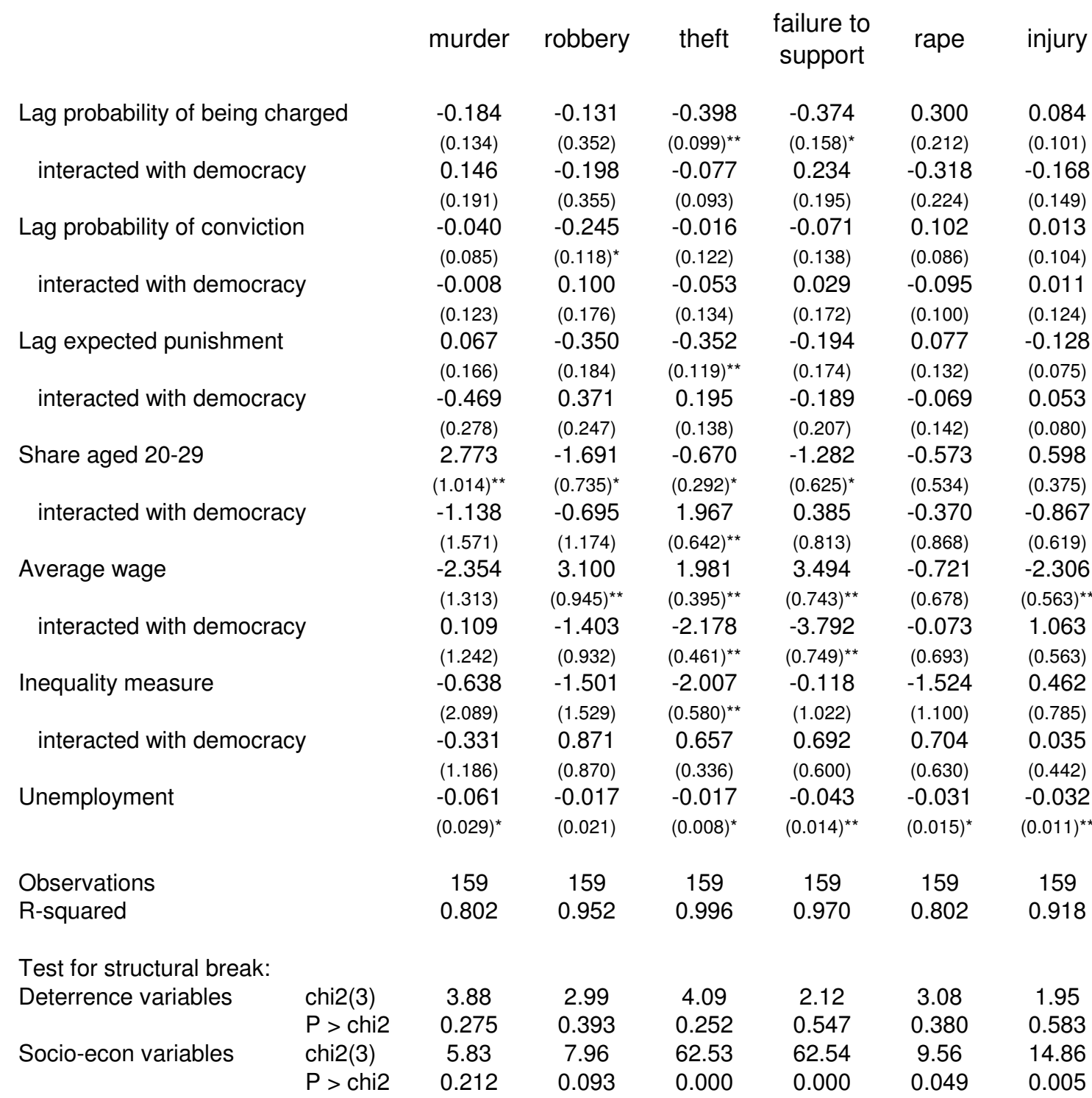

Absolute value of standard errors in parentheses. All equations include region and year dummies.

All variables except unemployment are in logs.

${ }^{*}$ significant at $5 \%$; ** significant at $1 \%$ 


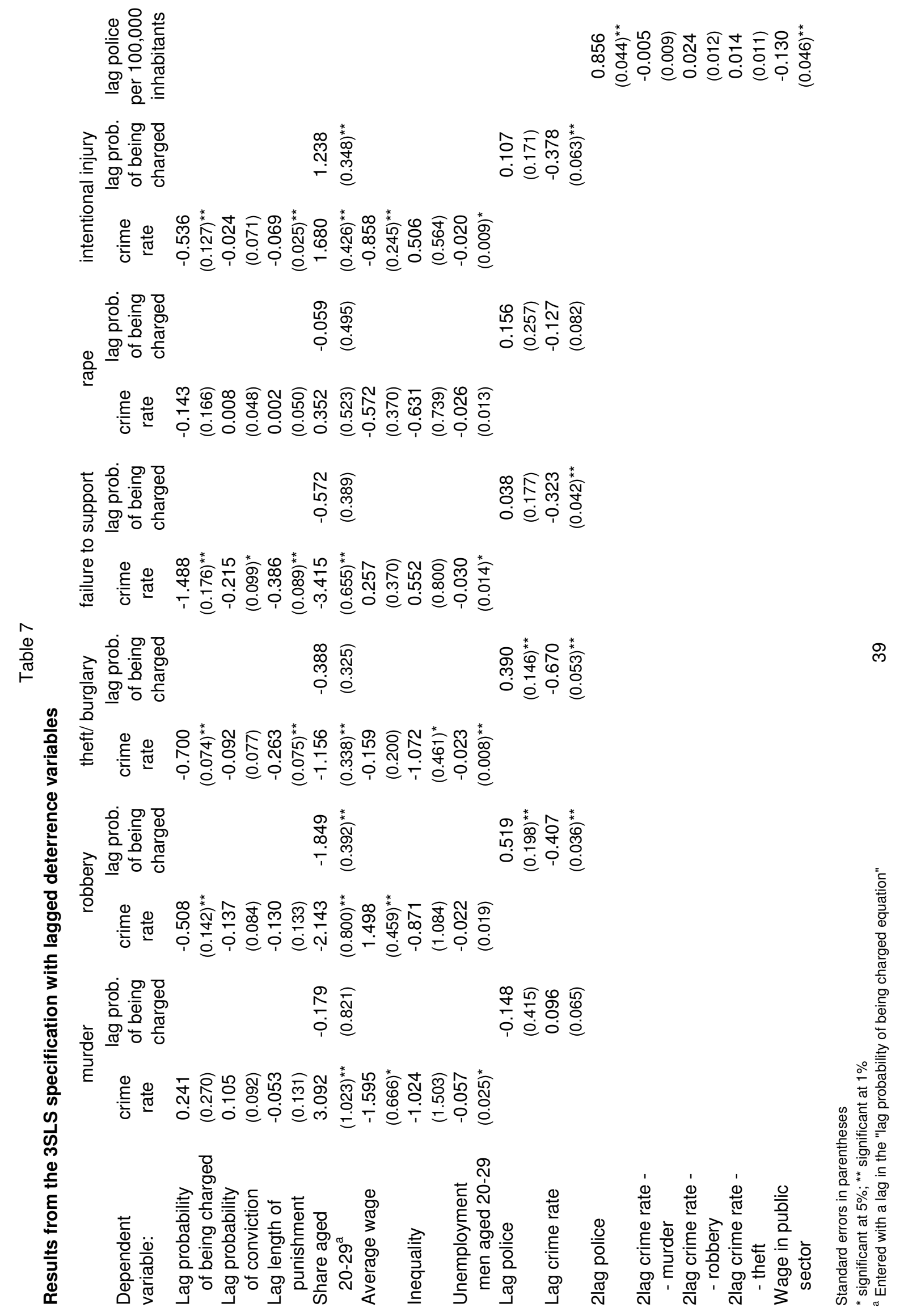


Table 8

\section{Contribution of weaker deterrence to the post-1989 growth in crime}

\begin{tabular}{|c|c|c|c|c|c|}
\hline & & $\begin{array}{c}\text { Actual } \\
\text { crime rate }^{*}\end{array}$ & $\begin{array}{c}\text { Percentage } \\
\text { change since } 1989\end{array}$ & $\begin{array}{l}\text { Predicted } \\
\text { crime rate }^{\star \star}\end{array}$ & $\begin{array}{l}\text { Fraction of the } \\
\text { change accounted } \\
\text { for by weaker } \\
\text { deterrence }\end{array}$ \\
\hline \multirow[t]{2}{*}{ Murder } & 1989 & 1.2 & & & \\
\hline & 2000 & 3.3 & $170 \%$ & 3.0 & $14 \%$ \\
\hline \multirow[t]{2}{*}{ Robbery } & 1989 & 16.8 & & & \\
\hline & 2000 & 45.8 & $173 \%$ & 30.1 & $54 \%$ \\
\hline \multirow[t]{2}{*}{ Theft } & 1989 & 196.4 & & & \\
\hline & 2000 & 1440.8 & $634 \%$ & 672.6 & $62 \%$ \\
\hline \multirow[t]{2}{*}{ Failure to support } & 1989 & 34.6 & & & \\
\hline & 2000 & 118.9 & $243 \%$ & 107.8 & $13 \%$ \\
\hline \multirow[t]{2}{*}{ Rape } & 1989 & 5.5 & & & \\
\hline & 2000 & 5.1 & $-7 \%$ & 4.9 & $-58 \%$ \\
\hline \multirow[t]{2}{*}{ Intentional injury } & 1989 & 47.5 & & & \\
\hline & 2000 & 71.6 & $51 \%$ & 55.1 & $68 \%$ \\
\hline
\end{tabular}


Individual researchers, as well as the on-line and printed versions of the CERGE-EI Working Papers (including their dissemination) were supported from the following institutional grants:

- Economic Aspects of EU and EMU Entry [Ekonomické aspekty vstupu do Evropské unie a Evropské měnové unie], No. AVOZ70850503, (2005-2010);

- Economic Impact of European Integration on the Czech Republic [Ekonomické dopady evropské integrace na ČR], No. MSM0021620846, (2005-2011);

Specific research support and/or other grants the researchers/publications benefited from are acknowledged at the beginning of the Paper.

(c) Libor Dušek, 2005

All rights reserved. No part of this publication may be reproduced, stored in a retrieval system or transmitted in any form or by any means, electronic, mechanical or photocopying, recording, or otherwise without the prior permission of the publisher.

Published by

Charles University in Prague, Center for Economic Research and Graduate Education (CERGE) and

Economics Institute (EI), Academy of Sciences of the Czech Republic

CERGE-El, Politických vězñu 7, 11121 Prague 1, tel.: +420 224005 153, Czech Republic.

Printed by CERGE-EI, Prague

Subscription: CERGE-El homepage: http://www.cerge-ei.cz

Editors: Directors of CERGE and EI

Managing editors: Deputy Directors for Research of CERGE and EI

ISSN 1211-3298

ISBN 80-7343-068-1 (Univerzita Karlova v Praze, CERGE)

ISBN 80-7344-057-1 (Národohospodářský ústav AV ČR, Praha) 
CERGE-EI

P.O.BOX 882

Politických vězňů 7

11121 Praha 1

Czech Republic http://www.cerge-ei.cz 